\title{
Is There More to A Visual Art Exhibition than just Art?
}

\author{
Bianca Manners \\ North-West University \\ E-Mail: 20652445@nwu.ac.za \\ Hanneri Borstlap \\ North-West University \\ E-Mail: Hanneri.Borstlap@nwu.ac.za \\ Melville Saayman \\ North-West University \\ E-Mail: Melville.Saayman@nwu.ac.za
}

\begin{abstract}
The purpose of this research was to determine the critical success factors for a visual art exhibition-specifically, a national arts festival. A structured questionnaire served as the instrument for collecting data. The questionnaire was distributed by trained fieldworkers at three venues that served as visual art exhibition galleries at the Aardklop National Arts Festival. Convenience sampling was used to gather 305 questionnaires from the three venues used as art exhibition galleries. The statistical analysis was done in two stages. The first stage included a two-way frequency table in order to determine the profile of respondents at these visual art exhibitions. In the second stage, a principal axis factor analysis was used to determine the five critical success factors identified in this research: venue and accessibility, catering, marketing, exhibition and display aspects, and health and safety. It was the first time that this type of research was implemented at a visual art exhibition at an art festival. Therefore, this research contributes significantly to the literature, specifically by creating a memorable visitor experience at a visual art exhibition with regard to important critical success factors.
\end{abstract}

Keywords: Critical Success Factors, Visual Art Exhibitions, Memorable Visitor Experience, Factor Analysis 


\section{INTRODUCTION}

Festivals and events are among the fastest-growing segments of tourism in the world (Goeldner, Richie \& McIntosh, 2000). Since the Grahamstown National Arts Festival in 1974, the first national arts festival in South Africa (Saayman \& Saayman, 2006; Snowball \& Webb, 2008), the country has experienced an unexpected growth in festivals. However, this growth only came after 1994, ironically enough when the government cut budgets for arts due to a greater focus on the provision of housing, education, and health services to the less fortunate citizens in the country (Belfiore \& Bennett, 2007; Dobson \& West, 1990; Hendon, 1990; Morrison \& West, 1986; Reiss, 2001; Saayman \& Saayman, 2006). Consequently, entrepreneurs and the private sector had to fill the void, with the result being that more art festivals were launched.

One such festival is the Aardklop National Arts Festival (also referred to as “Aardklop”), which celebrated its sixteenth birthday in October 2013 (Botha, Viviers \& Slabbert, 2012; Saayman \& Saayman, 2006). This festival provides a quality platform for the promotion of the arts and supports the artist community while enriching the local society (Lee, Liu, Chung \& Ho, 2015). Furthermore, Saayman, Douglas and De Klerk (2008) mentioned that Aardklop incorporates theatre, dance, music, cabaret and visual arts during a week-long programme at different venues in Potchefstroom. The focus of this study is the visual art exhibitions held at three different venues-namely, the North-West University's Botanical Garden, Sanlam Auditorium and Gallery. During Aardklop, these venues are used to display the art of up-and-coming artists as well as artists with a reputable status. According to Boll (2009), art galleries support and promote young artists by helping them develop and arrange exhibitions that attract collectors and buyers; art galleries are thus the intermediary or link to the art market. The number of people visiting festivals such as Aardklop (specifically, art galleries and exhibitions at festivals) is still on the increase (Higgs, Polonsky \& Hollick, 2005; Slater, 2007). Most of the arts festivals in South Africa are younger than 15 years, but with this growth came a boom in visual arts and competition amongst art galleries, which has resulted in art organisations mirroring a business-like approach that emphasises revenue production, marketing and promotion (Higgs et al., 2005). Artists and arts organisations need an audience, and one of the main tasks of management is to build this audience (Boorsma, 1998). Rogoff, Lee and Suh (2004) further mentioned that internal and external factors are determinants of business success, including factors that are beyond the control of the manager. Management must therefore shift from an art-centred business to a more clientfocused enterprise (Shaw, 2002). Introducing collaborative and effective marketing models (product promotion, market accessibility and networking) can thus lead to the 
diversifying of revenue sources by obtaining new audiences, products, venues and multi-art experiences (Kader, Mohamad \& Ibrahim, 2009; Radbourne, 1997). This fact, according to Higgs et al. (2005) has stimulated a response on the part of the artists, who have become more concerned with effective management by means of different marketing and good service delivery. The different approach is becoming increasingly important, as research indicates that $55 \%$ of the respondents prefer to buy art at galleries. This has led to the purpose of this paper, which is to determine the critical success factors of visual art exhibitions at the Aardklop National Arts Festival-in other words, to determine what managerial aspects visitors to art galleries see as important to satisfy their needs and persuade them to buy artworks.

According to Ralston, Ellis, Compton and Lee (2007), the quality of the delivered service is a dynamic concept, derived from understanding both how the visitor believes that service should be rendered and how a manager attempts to provide a service. Different types of events (e.g., music, sport and festivals) create a certain perception regarding the experience of visitors and the overall management and organisation of the event (Manners, 2014). Saayman (2009) states that the most important function in ensuring the success of an event is the ability of the event managers to assess the event, which (in this case) is a visual art exhibition.

This interpersonal concept does not simply imply good or satisfying perceptions of a service, but rather a memorable experience that the visitor is inspired to share with others (Rust \& Oliver, 1994). Citrine (1995) explains that one could refer to a memorable experience as the "wow" factor when designing events. Hence, when referring to a memorable experience, the wow factor is the factor perceived during an event which is worth remembering, even after the event is concluded. Manners (2014) adds that critical success factors for a memorable visitor experience can be defined as "aspects which are directly controlled by management in order to create an experience which not only exceeds expectations, but can also be treasured if managed effectively”. According to Hauptfleisch (2006), individuals might have a memorable experience when art is created and displayed at festivals, but it is not something that anyone can predict, plan or manage. However, according to Saayman, Marais and Krugell (2010), by implementing good evaluation and control measures, event managers determine not only the success of the event, but also the failures and shortcomings that might occur. This can be done by determining what visitors to an art exhibition regard as critical success factors. The reasons for determining these factors include being able to manage change effectively; being able to sell more art-in this case, by offering what visitors need; planning more effectively; and managing visitor flow more effectively. 


\section{LITERATURE REVIEW}

Myerscough (1988) defines the art sector as "independent provision alongside grand-aided activities and it covers the museums and galleries, theatres and concerts, creative artists, community arts, the crafts, the screen industries, broadcasting, the art trade, publishing and the music industries”. The word galleries often means different things to different people, as galleries engage in a multitude of visitor functions such as entertaining, informing, storytelling, constructing arguments, educating, defining and translating the otherwise unfamiliar and inaccessible into the familiar and accessible (Axelsen, 2006).

Research has indicated that individuals occasionally perceive the gallery environment as being stuffy, boring, static and unwelcoming or as a place of in-house terminology, ambiguous discussions and where one is either inside or outside the club (Axelsen, 2006; Cross, 2004; Davies, 1994; Kawashima, 1999; Prentice, 1994; Prentice, Davies \& Beeho, 1997). Bordieu (1984) adds to this, stating that visual art is one of the fields where cultural practices function in a manner which reproduces the class structure. This is quite evident, as social factors such as education, class, ethnicity and age group all play a role in who the visitors to these establishments are (Hood, 1983). Although art galleries are trying to become more accessible to the general public, there is still the recurrent criticism that they are perceived as exclusive. This exclusiveness is a cause for concern, as galleries have explicitly adopted policies of pursuing more equal access to and participation in the arts (O’Hagan, 1996), which has resulted in the art gallery becoming a public place and no longer the franchise of only the few, like it was in earlier times (Axelsen, 2006). Galleries' emergence from the shadows of being accessible only for the privileged into a monarchy of mass culture has transformed the art institutions, where a mind shift had to occur in order to focus more on the visitor experience (Axelsen, 2006).

Managers of art exhibitions have to consider various aspects that have to be managed in order to create a successful event and memorable experience (Manners, 2012). However, a variety of aspects lying beyond the primary focus of the attraction - in this case, the art exhibition-affect the visitor experience (Connell \& Meyer, 2010). Tassiopoulos (2000) states that event management is designed to control and manage event resources. Allen, O’Toole, McDonnell and Harris (2005) are of the opinion that event management consists of numerous areas, such as planning, leading, marketing, designing, budgeting and control, risk management, logistics, staging and evaluation. There are thus a number of aspects that event managers need to consider (Manners, 2012); these aspects form part of the experience 
of the visitors' expectations and influence their perception of the event (Matthew, 2008).

Manners (2012) states that two aspects regarding the organisation of the event should be managed to meet visitors' expectations: the artist and management aspects. These aspects are also known as critical success factors. Managerial aspects (i.e., aspects that can be controlled) include entertainment, technical aspects, food and beverage, marketing, entrance, transport, information, layout, accommodation, parking, community involvement, emergency, infrastructure and venue (Bowdin, Allen, O’Toole, Harris \& McDonnell, 2006; Matthew, 2008; Silvers, 2004). However, an event manager cannot control certain aspects, inclduing the expectations, behaviour and attitudes of the visitors as well as a number of factors that are largely outside the control of either the gallery, exhibition or visitor, such as climatic conditions and the mix of people visiting the exhibition at one time (Bowdin et al., 2006; Manners, 2012; Matthew, 2008; Silvers, 2004; Swarbrooke, 2002).

Other aspects include the mood of the visitor (Hull, 1990) as well as the availability and quality of off-site amenities, such as signposting, local accommodation and local services (Yale, 1997). The visitor's experience entails an interrelationship and a mixture of the critical success factors and will vary for different individuals who visit an art exhibition (Connell \& Meyer, 2010).

In a few key areas, things must go right for the business (in this case, an art exhibition) to flourish, and areas of activities should receive constant and careful attention from management. Critical success factors are also referred to as the factors that affect the ability to thrive in the marketplace; these include strategic elements, product attributes, capital, competencies, competitive capabilities, and business outcomes that spell the difference between profit and loss (Slabbert \& Saayman, 2003). Brotherton and Shaw (1996) add that critical success factors, and the extent to which they are achieved, will regulate the success of a company and business.

Thus, critical success factors not only contribute to the success of the event (in this case, an art exhibition), but also create a memorable experience which, hopefully, might also lead to greater sales and therefore income (Manners, 2012). Ferdinand and Williams (2013) state that a memorable event is created when the distinct elements involved in the management of events are brought together into a seamless, holistic experience. According to Beeho and Prentice (1997) and Masberg and Silverman (1996), the visitor's experience is multi-dimensional, and there is a need for tourism sites, such as art galleries, to be carefully managed. It is therefore crucial to meet the needs of the visitor and understand what the visitor wants to achieve through the anticipated experience (Van der Wagen, 2005). 
According to Singh (2009), events such as exhibitions should be evaluated based on the critical success factors in order to determine which factors are important for a memorable experience. Determining these factors will assist management in developing and improving a memorable experience for individuals attending an art exhibition; it will also ensure that all the management aspects are managed successfully. Manners' (2012) research specifically focused on what visitors regard as important critical success factors for a live music performance held in South Africa. In order of importance, these factors included general management, venue and technical aspects, marketing, accessibility and parking, amenities, and catering and souvenirs. Manners (2014) further compared the same critical success factors at the same concerts, but at different locations. These results indicated that, at the different locations, each concert's visitors regard different critical success factors as being more important than those at the other locations. This clearly indicates that visitors to live music performances vary not only from location to location, but also from what the various locations' visitors from the same genre regard as important critical success factors. Furthermore, Manners (2014) determined the difference amongst critical success factors between various music genres. Venue and technical aspects were considered the most critical factor, followed by accessiblity, general management, marketing, and amenities. Statistically significant differences were identified when these critical success factors were compared in various music genres. Williams and Saayman (2013) conducted research not only at a music event, but also at a two-day festival, where the requirements of visitors to the Cape Town International Jazz Festival were determined. Five factors were identified: value and quality, quality venues, hospitality factors, information dissemination, and marketing and sales. Their research revealed that different markets have different critical success factors that influence the experience of visitors when attending an event. Davis and Swanson (2009) identified six factors based on the consumer's experience of the performing arts. This study was performed internationally, and the factors that were identified were employee quality, experience value, access, ancillary quality, and visual aesthetics.

Other studies that determined the critical success factors include those of Marias (2009), who identified seven critical success factors at a wine festival (i.e., entertainment and activities, route development, wine farm attributes, accessibility, festival attractiveness, effective marketing, and quality and good management), and Erasmus (2011), who also identified seven critical success factors, based on tourists' experience at an arts festival (i.e., quality shows and stalls, safety and personnel, venues, activities and community, parking and restaurants, marketing and accessibility, 
and accommodation and ablutions). The latter research emphasises the significance of determining the critical success factors from the perspective of the visitors, whereas the results of these studies have also indicated that various critical success factors can be controlled by the event organisers. The results also indicate that the critical success factors differ from one tourism operation (event) to another, stressing that researchers need to conduct more studies on various tourism events to determine the factors that determine the success thereof.

\section{METHOD OF RESEARCH}

This section will describe the questionnaire (3.1), the sampling method and survey (3.2) and the statistical analysis (3.3).

\section{Questionnaire}

A structured questionnaire served as the instrument for collecting the data. The questionnaire used in the survey was divided into two sections:

- Section A determined the socio-demographic information of visitors to the art galleries and included questions to determine their gender, age, home language, marital status, and province of residence.

- Section B determined the critical management factors, based on the work of Manners (2012), Erasmus (2011) and Marais (2009), although the questionnaire was modified to relate more specifically to an art exhibition. Thirty management aspects relating to general management were taken into consideration, such as the layout of the exhibition, parking, security, accessibility, and food and beverages. These aspects were measured on a five-point Likert scale, where 1 indicated not at all important, 2 slightly important, 3 important, 4 very important and 5 extremely important.

\section{Sampling Method and Survey}

A convenience sampling method was used. Israel (2009) explains that in a population of 50,000 (N), 204 respondents (n) are considered representative with a sampling error of $7 \%$. The 305 questionnaires received were more than adequate and were thus included in further analysis. Trained fieldworkers distributed questionnaires at the Clover Aardklop exhibition from 23 to 28 September 2013 at the Botanical Garden, Sanlam Auditorium/Alumni Hall and Gallery. Questionnaires were handed out to a range of visitors with regard to different non-homogeneous age groups and gender groups. Willing participants completed the questionnaire prior to or after the exhibition. The authors made use of the total number of visitors to the Clover 
Aardklop Festival (Report, 2012), as there was no access control to determine the number of visitors to the art exhibition.

\section{Statistical Analysis}

The statistical analysis was done in two stages by using Microsoft Excel to capture the data and SPSS (SPSS Inc., 2010). First, a general profile of the respondents was compiled using two-way frequency tables. Second, a principal axis factor analysis was performed to determine the critical success factors of a memorable visitor experience. An oblimin rotation with Kaiser's normalisation was performed on the 30 management items to explain the variance-covariance structure of a set of variables through linear combinations of these variables. The Kaiser-Meyer-Olkin measure of sampling adequacy was also used to determine whether the covariance matrix was suitable for the factor analysis. Kaiser's criteria for the extraction of all factors with eigenvalues larger than unity were used, as they were considered to explain a significant amount of the variation in the data. The average inter-item correlations were also computed as another measure of reliability; according to Clark and Watson (1995), they should lie between 0.15 and 0.55 . The results from the statistical analysis are discussed in the next section.

\section{RESULTS}

The profile of the attendants at the art exhibition, as well as the results of the factor analysis, is discussed in this section.

\section{Profile of The Respondents}

The majority of the respondents who visited the Clover Aardklop Art Exhibition were female (62\%), between the ages of 50 and 64 (39\%), Afrikaans speaking (90\%) and either married (55\%) or single (25\%). These visitors are mainly from Gauteng (42\%) and North-West Province (37\%), spending an average of 3.5 nights in Potchefstroom. The visitors indicated that they attend art exhibitions an average of 6.7 times a year and prefer to buy art spontaneously (37\%) or, in some cases, rarely (30\%). The majority prefer to buy paintings (93\%) or drawings (80\%). They spend an average of R421,80 on these artworks and prefer to buy directly from the artist (59\%) or at galleries (55\%). Seventy-three percent of the visitors had heard about the art exhibition by word of mouth and newspapers (60\%), and 62\% visited the exhibition by themselves. 


\section{Results of The Factor Analysis}

The pattern matrix of the principal axis factor analysis, using an oblimin rotation with Kaiser's normalisation, identified five management factors (critical success factors) that were labelled according to similar characteristics (Table 1). These factors accounted for $59 \%$ of the total variance. All factors had relatively high reliability coefficients, ranging from 0.720 (lowest) to 0.893 (highest). The average values of the inter-item correlation coefficient, 0.424 and 0.562, imply internal consistency for all factors. All items loaded on a factor with a loading greater than 0.3 , and the relatively high factor loadings indicate a reasonably high correlation between the factor and their component items. The Kaiser-Meyer-Olkin measure of sampling adequacy of 0.97 indicates that the patterns of the correlation are relatively compact and yield distinct and reliable factors (Field, 2009, p. 640). Bartlett's test of sphericity also reached statistical significance $(\mathrm{p}<0.001)$, supporting the factorability of the correlation matrix (Pallant, 2007, p. 197).

Factor scores were calculated as the average of all items contributing to a specific factor so that the scores could be interpreted on the original five-point Likert scale measurement. As shown in Table 1, the following critical success factors were identified:

\section{- Factor 1 : Venue and Accessibility}

This factor has a mean value of 3.854 and revealed the importance of the venue and accessibility. It was considered the second most important critical success factor for a memorable visitor experience. The factor comprises effective signage, parking, regulated traffic flow, traffic control, ticket sales, adequate ATM facilities, security, adequate information at the venue, and communication about the parking and transport prior to their visit. According to Marias (2009), accessibility is the fourth most important factor for managing a wine festival, whereas Erasmus (2011) rates it as the sixth most important critical success factor at an art festival. Parking, also identified by Erasmus (2011), was identified as the fifth most important factor.

\section{- Factor 2: Catering}

This factor has a mean value of 2.980 and was considered the least important critical success factor. Catering comprises the following variables: variety of food and beverages, affordable food and beverages at the venue, and freebies from the sponsors. Manners (2012) identified amenities and catering as the second lowest critical success factor, whereas Erasmus (2011) identified restaurants, which forms part of catering, as the fifth most important critical success factor. 


\section{- Factor 3: Marketing}

This factor has a mean value of 3.622 and was considered the second lowest critical success factor. Marketing had been identified as a critical success factor in various studies. Marais (2009) and Erasmus (2011) also identified marketing as the second least important critical success factor.

\section{- Factor 4: Exhibition and Display Aspects}

This factor has the highest mean value-namely, 4.275-and was therefore considered the most important critical success factor for a memorable visitor experience at an art exhibition. The factor captured different aspects, including good all-round visibility and layout, good layout of venue, comfortable seating, goodquality sound and lighting, and punctuality of exhibition starting time.

\section{Factor 5: Safety}

This factor comprises general management factors and has a mean value of 3.735, making it the third most important critical success factor in this study. Manners’ (2014) findings support this factor.

Table 1 Critical Success Factors of Visitors to The Visual Arts

\begin{tabular}{lllll}
\hline CSFs and items & $\begin{array}{l}\text { Factor } \\
\text { loading }\end{array}$ & $\begin{array}{l}\text { Mean } \\
\text { value }\end{array}$ & $\begin{array}{l}\text { Reliability } \\
\text { coefficient }\end{array}$ & $\begin{array}{c}\text { Average } \\
\text { inter-item } \\
\text { correlation }\end{array}$ \\
\hline Factor 1: Venue and accessibility & & $\mathbf{3 . 8 5 4}$ & $\mathbf{0 . 8 9 3}$ & $\mathbf{0 . 4 2 4}$ \\
\hline Effective signage and directions to the venue & 0.62 & & & \\
\hline Adequate parking at the venue & 0.60 & & & \\
\hline Effective, regulated traffic flow after the exhibition & 0.60 & & \\
\hline All information given about the exhibition was correct & 0.56 & & \\
\hline Adequate ATM facilities/card machines & 0.51 & & \\
\hline Adequate security at parking areas & 0.46 & & \\
\hline Accessibility for the disabled & 0.41 & & \\
\hline $\begin{array}{l}\text { Effective ticket sales prior to Aardklop (e.g. online } \\
\text { bookings) }\end{array}$ & 0.35 & & \\
\hline Adequate information at the venue & 0.33 & & \\
\hline $\begin{array}{l}\text { The opportunity to meet the artist at the exhibitions } \\
\text { (e.g. for photos or autographs) }\end{array}$ & 0.30 & & \\
\hline $\begin{array}{l}\text { Communication about parking and transport options } \\
\text { prior to the event }\end{array}$ & 0.32 & & \\
\hline Effective traffic control to and from the venue & 0.39 & & \\
\hline
\end{tabular}


Table 1 Critical Success Factors of Visitors to The Visual Arts (continued)

\begin{tabular}{|c|c|c|c|c|}
\hline CSFs and items & $\begin{array}{l}\text { Factor } \\
\text { loading }\end{array}$ & $\begin{array}{l}\text { Mean } \\
\text { value }\end{array}$ & $\begin{array}{l}\text { Reliability } \\
\text { coefficient }\end{array}$ & $\begin{array}{l}\text { Average } \\
\text { inter-item } \\
\text { correlation }\end{array}$ \\
\hline Factor 2: Catering & & 2.980 & 0.720 & 0.462 \\
\hline $\begin{array}{l}\text { Variety of food and beverages (e.g. halaal, vegetarian, } \\
\text { wines and soft drinks) }\end{array}$ & 0.76 & & & \\
\hline Affordable food and beverages at venue & 0.67 & & & \\
\hline Freebies from sponsors & 0.56 & & & \\
\hline Factor 3: Marketing & & 3.622 & 0.810 & 0.473 \\
\hline $\begin{array}{l}\text { Adequate pre-concert performances or pre-show } \\
\text { entertainment }\end{array}$ & 0.30 & & & \\
\hline $\begin{array}{l}\text { Variety of marketing media used (e.g. magazines, } \\
\text { radio and posters) }\end{array}$ & 0.74 & & & \\
\hline Adequate/Effective marketing prior to the event & 0.67 & & & \\
\hline $\begin{array}{l}\text { User-friendly and accessible information regarding the } \\
\text { exhibitions (e.g. websites, radio advertisements and } \\
\text { posters) }\end{array}$ & 0.57 & & & \\
\hline $\begin{array}{l}\text { Correct information given through marketing (e.g. } \\
\text { date, time, venue and transport options) }\end{array}$ & 0.49 & & & \\
\hline Factor 4: Exhibition and display aspects & & 4.275 & 0.826 & 0.562 \\
\hline Good all-round visibility and layout & 0.80 & & & \\
\hline Good layout of venue and comfortable seating & 0.71 & & & \\
\hline Good-quality sound and lighting & 0.68 & & & \\
\hline Punctuality of exhibition starting time & 0.46 & & & \\
\hline Factor 5: Safety & & 3.735 & 0.833 & 0.502 \\
\hline $\begin{array}{l}\text { Visibility of emergency and security staff in and } \\
\text { around the venue }\end{array}$ & 0.68 & & & \\
\hline $\begin{array}{l}\text { Communication about the adequate safety } \\
\text { measures/precautions in place during the exhibitions } \\
\text { in case of an emergency (e.g. evacuation } \\
\text { plan/emergency exits) }\end{array}$ & 0.66 & & & \\
\hline $\begin{array}{l}\text { Adequate, clean and hygienic ablution facilities } \\
\text { inside/outside the venue }\end{array}$ & 0.61 & & & \\
\hline $\begin{array}{l}\text { Friendly and professionally trained staff who are } \\
\text { easily noticeable in and around the venue }\end{array}$ & 0.55 & & & \\
\hline Appropriate gate-opening time prior to event & 0.53 & & & \\
\hline PERCENTAGE VARIANCE EXPLAINED & $59 \%$ & & & \\
\hline
\end{tabular}




\section{FINDINGS AND IMPLICATIONS}

Based on the results, several findings and implications were identified in this study. First, the notion that critical success factors differ from one tourism product to the next is hereby confirmed (Marais, 2009; Erasmus, 2011; Manners, 2012; Williams, 2012). This is evident from the five critical success factors identified in this research: venue and accessibility, catering, marketing, exhibition and display aspects, and safety.

Second, the research confirms that, from a visitor's perspective, venue and accessibility as well as exhibitions and display also contribute to a memorable experience at an arts exhibition; in other words, these factors contribute to the visitor's level of satisfaction on the one hand, but also complement each other when considering their mean values (3.85 and 4.27, respectively). This implies that art exhibition managers need to ensure that these two factors are well managed. The exhibition and display are seen as the main reason why people attend the art festival, although the festival has many other activities and attractions to offer. Winfield and Webber (2011) explain that the objective of the exhibition is to bring together the purveyor of a message and the visitors and to allow face-to-face contact between artist and the target audience (in this case, the visitors). They are of the opinion that this will create positive emotions and can result in repeat visitation.

These facts emphasise the importance of art exhibition managers ensuring a good layout of artists' works and sufficient space for the exhibition; hence, a proper venue and good lighting are essential. These two aspects are extremely important at a visual art exhibition, specifically during an art festival, as artists use any venue that is well located to display their art, but (due to limited space) the display of artworks results in art clutter and inadequate lighting, as these venues are not designed for art exhibitions. This influences the visitors' experience in appreciating and possibly buying the art on display.

Concerning the venue and accessibility, exhibition managers should consider the needs of different types of visitors, including the elderly, disabled and people who are not familiar with the exhibition (Majewski, 1998). A recent study conducted by Milligan, Nieuwenhuijsen and Grawi (2014) also confirms this finding and stresses the importance of accessibility, in terms of not only people's movement, but also information dissemination. The curator or the managers of the exhibition can improve this experience by mapping the different locations through coordinates or by giving each visitor a hard copy on arrival (or a soft copy to download directly from the website). It is important to provide the visitor with all the information prior to their visit regarding the parking, artist and venue to ensure a memorable visit. This can be done by means of building databases, emailing them regarding any changes of venue 
or artist, or providing other relevant information prior or during the exhibition. The manager can further capitalise on social media, such as Facebook, Twitter, Instagram, LinkedIn and YouTube.

In addition, Shubik (2003) states that the success of galleries or art exhibitions depends on the networking, museums, private collectors and other cultural institutions by means of exhibition openings. Consumers do not form part of this network, causing them to feel excluded and not welcome in the gallery. In order to reach a large market, artists attend festivals and fairs attracting thousands of visitors, making this an easy marketing tool (Zorloni, 2013). In this context, marketing was also identified as the fourth most important factor, thereby supporting research by Marais (2009) and Erasmus (2011).

Catering was regarded as the least important critical success factor of the five, thereby both supporting and contradicting previous studies. However, when catering is offered at an arts exhibition, it is proof that visitors' different needs are taken into consideration, especially when a selection of food is made available. In addition, catering can contribute to visitors spending more time at the exhibition.

The last factor, safety, was identified and also considered as the third most important critical success factor, thereby supporting Manners (2014). In this context, safety implies professionally trained staff members who are easily noticeable and can assist visitors with information about what to do in case of an emergency. It also includes health and safety, which require clean and hygiene ablution facilities.

Lastly, art clutter should be avoided, as it could also pose a risk, especially when artworks are stacked in hallways or in front of exit paths, such as doors and windows. The layout of the exhibition should be spacious to encourage the free flow of crowds and handicapped persons, and loose-standing or wobbly paintings or artworks should be avoided to prevent injury to the visitors or damage to the art. Therefore, it is recommended that visual art exhibition managers should attend short courses on installing and displaying art in order to enhance the experience for the exhibition attendees. Furthermore, managers also have to evaluate their events continuously and specifically evaluate the different types of art exhibitions in order to ensure that the event in itself satisfies the visitors' requirements when an art exhibition is being attended. This can be determined by knowing the motives and needs of these visitors.

\section{CONCLUSION}

The purpose of this research was to determine the critical success factors for visual art exhibitions at an art festival. It is clear from the findings that critical factors differ from one event to another, which confirms the importance of this type of 
research. The findings also support the notion that managers need to be aware of visitors' needs. Five factors were identified as important for a memorable visitor experience: venue and accessibility, catering, marketing, exhibition and display aspects, and safety. This study marks the first time that such research was conducted at a visual art exhibition at an art festival in South Africa; to the authors' best knowledge, it has never been done before anywhere else in the world. Thus, this research contributes significantly to existing literature, specifically related to creating a memorable visitor experience at a visual art exhibition with regard to important critical success factors. The research can be used by managers to enhance their management strategies in order to improve the visitors' experience when a visual art exhibition is attended. It also stresses the aspects that require "special" attention, as these aspects could influence visitors in buying art. Apart from this, tertiary educational facilities can also use this information in educating future managers in the art exhibition industry to ensure successful events and the implementation of eventspecific strategies.

However, different types of art exhibitions occur, and it is important for managers to be aware of the different aspects that individuals may consider as being important when these exhibitions are attended. Therefore, critical success factors should be determined at different types of art exhibitions in order to compile guidelines for managers to implement event-specific strategies for a specific art exhibition, which may increase the memorable experience and art sales when individuals attend various art exhibitions. Managers should also consider the different aspects that are more important for a successful event compared to those the art exhibition attendees consider important for a memorable experience. Art exhibition managers' perspective of important aspects should also be determined by implementing a qualitative-research approach that can be compared to the important critical success factors in order to determine possible gaps in the management process. Finally, research should be conducted before and after a visual art exhibition attendee has visited an art exhibition in order to determine what the attendee expected to experience and what the attendee actually experienced when the visual art exhibition was over.

\section{REFERENCES}

Allen, J., O’Toole, W., McDonnell, I. \& Harris, R. (2005). Festivals and special event management ( $3^{\text {rd }}$ ed). Milton, Qld: John Wiley. 
Axelsen, M. (2006). Defining special events in galleries from a visitor perspective. Journal of Convention \& Event Tourism, 8(3), 21-43. http://dx.doi.org/10.1300/J452v08n03_02

Beeho, A., \& Prentice, R.C. (1997). ASEB grid analysis and the Black Country Museum in the West Midlands of England: Understanding visitors experiences as a basis of product development. In L.C. Harrison and W Husbands (Eds). Practicing Responsible Tourism. International Case Studies in Tourism Planning, Policy and Development. New York: John Wiley.

Belfiore, E., \& Bennet, O. (2007). Rethinking the social impacts of the arts. International Journal of Cultural Policy, 13(2), 135-151. http://dx.doi.org/10.1080/10286630701342741

Boll, D. (2009). Kunst ist kauflich freie Sicht auf den Kunstmarkt. Zurich: Ruffer \& Rub.

Boorsma, M. A. (1998). Kunstmarketing: hoe marketing kan bijdragen aan het maatschappelijk functioneren van kunst, in het bijzonder van toneelkunst in Nederland. Groningen: Rijksuniversiteit Groningen.

Botha, K., Viviers, P. \& Slabbert, E. (2012). What really matters to the audience: analyzing the key factors contributing to arts festival ticket purchases. South African Theatre Journal, 26(1), 22-44. http://dx.doi.org/10.1080/10137548.2012.754080

Bourdieu, P. 1984. Distinction: A social critique of the judgment of taste. Harvard University Press: Campbridge, MA.

Bowdin, G., Allen, J., O’Toole, W., Harris, R. \& McDonnell, I. (2006). Event Management. $2^{\text {nd }}$ ed. Oxford: Elsevier.

Brotherton, B. \& Shaw, J. (1996). Towards an identification and classification of critical success factors in UK hotel plc. International journal of hospitality management, 15(2): 113-135. http://dx.doi.org/10.1016/0278-4319(96)00014-X

Citrine, K. (1995). Site planning for events. In Event operations. Port Angeles, Wash.: International Festivals and Events Association. (pp. 17-19).

Clark, L.A. \& Watson, D. (1995). Constructing validity: basic issues in objective scale $\begin{array}{llll}\text { development. } \quad \text { Psychological } & \text { 309-319), }\end{array}$ http://dx.doi.org/10.1037/1040-3590.7.3.309

Connell, J. \& Meyer, D. (2010). Modeling the visitor experience in the Gardens of Great Britain. Current issues in Tourism, 7(3), 183-216. http://dx.doi.org/10.1080/13683500408667979

Cross, J. 2004. Crossing the moat: Art museums and life-wide learning. Museums Australia, 13(1), 15-18. 
Davies, S. (1994). By popular demand. MGC, London.

Davis, J.C. \& Swanson, S.R. (2009). The importance of being earnest of committed: attribute importance and consumer evaluations of the live arts experience. Journal of nonprofit and public sector marketing, 21(1), 56-79. http://dx.doi.org/10.1080/10495140802111968

Dobson, L, \& West, E. 1990. Performing arts subsidies and future generations. Journal of behavioural economics, 19(1), 23-33. http://dx.doi.org/10.1016/00905720(90)90015-Y

Erasmus, I.J. (2011). Key success factors in managing the visitors' experience at the Klein Karoo National Arts Festival. (Master's dissertation, North-West University, Potchefstroom Campus. Retrieved from: http://millennium.nwu.ac.za/search $\sim$ S $/ \mathrm{t}+$ Key+success+factors+in+managing $+\mathrm{t}$ he+visitors $\{227\}$ a $\{492\}+$ experience+at+the+Klein+Karoo+National+Arts+Festi $\mathrm{va} /$ tkey+success+factors+in+managing +the+visitorsa+experience+at+the+klein+ karoo/-

$3 \% 2 \mathrm{C} 0 \% 2 \mathrm{C} 0 \% 2 \mathrm{CB} / \mathrm{exact} \& \mathrm{FF}=$ tkey+success+factors+in+managing+the+visitor s+experience+at+the+klein+karoo\&1\%2C2\%2C/indexsort=-.

Ferdinand, N. \& Williams, N.L. (2013). International festivals as experience production systems. Tourism Management, 34, 202-210. http://dx.doi.org/10.1016/j.tourman.2012.05.001

Goeldner, C.R., Richie, J.R.B. \& McIntosh, R.W. (2000). Tourism: principles, practices, philosophies ( $8^{\text {th }}$ ed). New York: John Wiley.

Hauptfleisch, T. (2006). Identifying identity: festival in South Africa and the search for cultural identity. New theatre quarterly, 22(2), 181-198.

Hausmann, A. (2010). German artist between Bohemian Idealism and entrepreneurial dynamics: Reflections on cultural entrepreneurship and the Need for start-up management. International Journal of Art Management, 12(2), 17-29.

Hendon, W. The general public's participation in art museums: Visitors differ from non-visitors, but not as markedly as case studies have indicated. American Journal of Economics and Sociology. October 1990, 49 (4), 439-457. http://10.1111/j.1536-7150.1990.tb02470.x

Higgs, B., Polonsky, M.J. \& Hollick, M. (2005). Measuring expectations: forecast vs. ideal expectations. Does it really matter? Journal of Retailing and Consumer Service, 12: 49-64. http://dx.doi.org/10.1016/j.jretconser.2004.02.002

Hood, M.G. (1983). Staying away: why people choose not to visit museums. Museum News, April: 50-57. 
Hull, R.B. (1990). Mood as a product of leisure: Causes and consequences. Journal of Leisure Research, 22, 99-111.

Israel, G.D. (2009). University of Florida IFAS Extension. Determining the sample size. Retrieved from http://edis.ifas.ufl.edu/pd00600pdf.

Kader, R.A., Mohamad, M.R.B. \& Ibrahim, A.H.C. (2009). Success factors of small rural entrepreneurs under the One-District-One-Industry Progamme in Malaysia. Contemporary Management Research, 5(2), 147-162. http://dx.doi.org/10.7903/cmr.1173

Kawashima, N. (1999). Knowing the public. A review of museums marketing literature and research. Museum Management and Curatorship, 17(1), 21-39. http://dx.doi.org/10.1080/09647779800301701

Lee, Y.K., Liu, T.L., Chung, F.T. \& Ho, H.H. (2015). Investigating the role of government policy and the environment on locals' loyalty to spring music festivals. Contemporary Management Research, 11(1), 35-54.

Manners, B. (2012). The critical success factors for managing the visitor experience at a major musical event. (Masters' dissertation: North West University. Potchefstroom Campus. (Retrieved from: http://millennium.nwu.ac.za/search $\sim$ S4?/tThe+critical+success+factors+for+man aging+the+visitor+experience+at+a+major/tcritical+success+factors + for + managi ng+the+visitor+experience+at+a+major/1\%2C1\%2C2\%2CB/frameset\&FF=tcriti cal+success + factors + for + managing + the+visitor + experience $+a t+a+$ major + mus \& $1 \% 2 \mathrm{C} \% 2 \mathrm{C} 2)$.

Manners, B. (2014). Critical assessment of live music performances in creating a memorable experience: A demand and supply perspective. (Doctor of philosophy thesis: North West University. Potchefstroom Campus. (In press ).

Marais, M. (2009). Key success factors in managing the Wacky Wine Festival. NorthWest University: Potchefstroom Campus (Doctoral dissertation, DissertationMCom.) 60p).

Masberg, B.A. \& Silverman. L.H. (1996). Visitor experience at heritage sites: A phenomenological approach. Journal of Travel Research, 4(1), 20-25. http://10.1177/004728759603400403

Matthew, D. 2008. Special event production: the process. Oxford: ButterworthHeinemann.

Morrison, W., \& West, E. (1986). Subsidies for the performing arts: evidence of voter preference. Journal of behavioural economics, 15 Fall: 57-72. http://dx.doi.org/10.1016/0090-5720(86)90051-3 
Myerscough, J.C. (1988). The economic importance of the arts. Policy Studies Institute, London.

O'Hagan, J.W. (1996). Access to and participation in the arts: The case of those with low incomes/ educational attainment. Journal of Cultural Economics, 20, 269282. http://dx.doi.org/10.1007/s10824-005-0282-4

Pallant, J. (2007). SPSS survival manual: a step by step guide to data analysis using SPSS Version 15. 3rd ed. New York: McGraw- Hill.

Prentice, R.C. (1994). Perceptual deterrents to visiting museums and other heritage attractions. Museum Management and Curatorship, 13, 264-279. http://dx.doi.org/10.1080/09647779409515408

Prentice, R.C., Davies, A., \& Beeho, A. (1997). Seeking generic motivations for visiting and not visiting museums and like cultural attractions. Museum Management and Curatorship, 16(1), 45-70. http://dx.doi.org/10.1080/09647779700501601

Radbourne, J. (1997). "Creative Nation - a policy for leaders or followers? An evaluation of Austalia's 1994 cultural policy statement” Journal of arts management, law and society, 26(4), 271-83. http://dx.doi.org/10.1080/10632921.1997.9942966

Ralston, L.S., Ellis, G.D., Compton, D.M. \& Lee, J. (2007). Staging memorable events and festivals: an integrated model of service and experience factors. International journal of event management research, 3(2), 24-38.

Reiss, A.H. (2001). Arts funding concerns are worldwide. Fund Raising Management, 47-48.

Rogoff, E.G., Lee, M.S., \& Suh, D.C. (2004). Who done it? Attributes by entrepreneurs and experts of the factors that cause and impede small business success. Journal of Small Business Management, 42(4), 364-376.

Rust, R.T., \& Oliver, R.L. (1994). Service quality: insights and managerial implications. In: Rust, R.T., Oliver, R.L. (Eds.), Service Quality: New directions in theory and practice. (pp. 1-19). California: Sage Publications.

Saayman, M. (2009). Hospitality, leisure and tourism management. $2^{\text {nd }}$ ed. Potchefstroom: Institute for Tourism and Leisure Studies.

Saayman, M., Douglas, M., \& De Klerk, S. (2008). Attributes of entrepreneurs at an arts festival. Southern African Journal of Entrepreneurship and Small Business Management, 2(1), 17-29. http://dx.doi.org/10.4102/sajesbm.v2i1.16

Saayman, M., Marais, M. \& Krugell, W.F. (2010). Measuring success of a wine festival: is it really that simple? South African Journal for Research in sport, 
physical education and recreation, 32(2), 95-108. http://dx.doi.org/10.4314/sajrs.v32i2.59299

Saayman, M. \& Saayman, A. (2006). Does the location of arts festival smatter for the economic impact? Regional science, 85(4), 569-584. http://dx.doi.org/10.1111/j.1435-5957.2006.00094.x

Shaw, S. (2002). Marketing-Indeem im kusntbetrieb. In L Pues, P. Rissa \& E. Quadt (Eds). Art-investor Handbuvch fur Kunst \& Investment (pp348-353) Munchen: FinanzBuch Verlag.

Shubik, M. (2003). Dealers in art. In R. Towse (ed.), A Handbook of Cultural Economics, (pp. 194 - 200). Cheltenham: Edward Elgar Publishing Limited.

Silvers, J. 2004. Professional event co-ordination. Hoboken, N.J.: Wiley.

Singh, S.R. 2009. Event Management. New Delhi: APH Publishing Corporation.

Slabbert, E. \& Saayman, M. (2003). Guesthouse management in South Africa. (2 ${ }^{\text {nd }}$ ed). Potchefstroom: Institute for Tourism and leisure Studies.

Slater, A. (2007). Escaping to the gallery': understanding the motivations of visitors to galleries. International Journal of Nonprofit and voluntary sector marketing, 12(1), 149-162. http://dx.doi.org/10.1002/nvsm.282

Snowball, J.D., \& Webb, A.C.M. (2008). Breaking into the conversation: cultural value and the role of the south African national arts festival from apartheid to democracy. International journal of cultural policy, 14(2), 149-164. http://dx.doi.org/10.1080/10286630802106326

Spss, I. (2012). IBM SPSS statistics version 21. Boston, Mass: International Business Machines Corp.

Swarbrooke, J. (2002). The development and management of visitor attractions $\left(2^{\text {nd }}\right.$ Ed). Oxford: Butterworth-Heinemann.

Tassiopoulos, D. (2000). Events: an introduction. In Tassiopoulos, D., ed. Event management. (pp.494). Lansdowne: Juta Education.

Thompson, D. (2008). The curios economics of contemporary art and auction houses. London: Aurum Press.

Van der Wagen, L. (2005). Event management for tourism, cultural, business and sporting events. ( $2^{\text {nd }}$ ed). Australia: Pearson.

Williams, K. (2011). Key success factors in managing the visitor experience at the Cape Town International Jazz Festival/Williams K (Doctoral dissertation, NorthWest University).

Williams, K. \& Saayman, M. (2013). Relationship between travel motives and key success factors of visitors at a jazz festival. South African Journal of Research in Sport, Physical Education and Recreation, 35(1), 183-202. 
Yale, P. (1997). From tourist attractions to heritage tourism. Huntingdon: ELM. 